\title{
A Case Study in the Architecture of Global Water Governance
}

\author{
Richard A. Meganck ${ }^{1,2}$ \& Richard E. Saunier ${ }^{3}$ \\ ${ }^{1}$ Team Leader and Professor, Institute for Water and Watersheds, Oregon State University, Corvallis, Oregon, \\ USA \\ ${ }^{2}$ Senior Advisor, UNESCO-Hidroex, Frutal, Brazil \\ ${ }^{3}$ International environmental consultant, Santa Fe, New Mexico, USA \\ Correspondence: Richard A. Meganck, 1100 Skookum Dr., Silverton, Oregon 97381, USA. E-mail: \\ rameganck@gmail.com
}

Received: August 1, 2014

Accepted: August 22, 2014 Online Published: August 25, 2014

doi:10.5539/enrr.v4n4p28

URL: http://dx.doi.org/10.5539/enrr.v4n4p28

\begin{abstract}
The purpose of this paper is to engender a more structured debate by all stakeholders with an interest in improved water management through development of either a global agreement or a series of agreements at regional levels. In the past decade various committees of the United Nations including the UN General Assembly and the UN Security Council have ramped-up the discussion on the importance of water to economic development, health and prosperity, human rights and even national and regional security (UNCESCR, 2002; UNGA, 2003; UNGA, 2010). All of this attention has catalyzed new fields of study and a robust international debate as to the responsibilities of "water rich" countries to those countries in less fortunate regions of the world and how to mitigate inevitable water conflicts. And while the U.S. is not classified as a "water poor" country, Canada's Ambassador to the U.S., Gary Doer, recently noted that the relationship with the U.S. would be increasingly impacted by water. "I think five years from now we will be spending diplomatically a lot of time and a lot of our work dealing with water. There will be pressure on water quality and water quantity"(Note 1). Shortly after these comments, President Obama acknowledged as much in his 28 May 2014 foreign policy speech by noting "...the spirit of cooperation that must energize the global effort to combat", among other issues, conflicts over "water and food" (Note 2). And if there is some degree of tension between neighbors as close as Canada and the U.S., imagine the tenor of the debate in other regions of the world with shared water resources and in come cases where one country entirely controls the water resources of another. Additionally, the importance of developing more precise goals and targets through the International Hydrological Program (UNESCO-IHP), the World Water Council (WWC), UN Water, the Millennium Development Goals, and the investment strategies of both the private sector and the NGO community cannot be overstated. This paper explores the importance of global water governance and outlines the possibilities of an international freshwater convention, optimistically one with binding responsibilities, leading to better water management.
\end{abstract}

Keywords: water convention, water treaty, water conflict mitigation, international freshwater convention

\section{Introduction}

The trajectory of 'water' from a resource with many competing sectorial themes (domestic, agricultural, industrial, recreational, protein source, transportation media, etc.) to its current position as fundamental to any development or investment discussion, demands a place in the global governance debate to address the increasing complexity of water use world-wide. Where does the issue of water fit into the overall discussion of economic development? How is water related to the ongoing World Trade Organization (WTO) discussions on subsidies and the development of new trading alliances? Will water futures (virtual or physical) be traded as widely as other 'commodities' on a global scale? Is water a commodity in the old 'natural resource' sense (something with market value to be sold) and/or a basic human right that should be shared without cost considerations? How will such developments be institutionalized in such a way that the outcome brings more order, rather than further isolation, a widening gap between water rich and water poor peoples and countries, and possible conflicts? Can virtual water be considered part of the Official Development Assistance (ODA) package of one country to another? As water gains importance, so do the types of questions that are posed, and with good reason: simply stated, water is life. 
First and foremost in our opinion, science must underscore the response to any of these questions. And, while scientists must confront all of the above issues, they must then be able to communicate the outcomes of such in language understood by the many different consumers of their research, including policy makers. Otherwise our 'Tower of Babble' approach will continue to plague international debate and understanding. For example, in recent years an entirely new vocabulary has developed to deal with the rapidly evolving milieu of water science, policy and management. Terms such as 'virtual water,' 'water footprint,' 'transboundary water,' and 'water nanotechnology' were unknown only a few years ago. Others, such as 'water scarcity' and 'water stress' were generally used interchangeably, while even 'old-school' terms such as 'water quality,' watershed management,' and 'water pollution' were used without much precision in international fora, in policy statements and even in the text of laws. Predictably, once water became integral to any discussion of international economic development and investment, misunderstanding also resulted from the lack of the precision demanded by the various user-groups water scientists, investors, and regulatory bodies. Unfortunately, the accelerating expansion of new terminology and corresponding acronyms has not necessarily helped our collective understanding (Saunier \& Meganck, 2009). Natural scientists, social scientists, engineers, policy makers and politicians all contribute to the debate as to how water and its many aspects and applications should be defined and managed: a healthy sign, but are they speaking at, to, or around each other?

Apart from language, the matrices used in defending or countering any position are, simply stated, mind-boggling. The myriad of facts and figures regarding water cited in attempting to foster transparent debate and yet defend entrenched positions are well known, easily confused, and many times manipulated to support divergent opinions of the same issue. According to a recent UN Water report the potential demand for water is projected to grow by more than $50 \%$ potentially resulting in nearly two-thirds of the world's population living in water-stressed conditions by 2025 if current consumption trends continue. Currently about $40 \%$ of the world's population lives in transboundary basins and nearly 2 billion people are dependent on groundwater (UN Water, 2014). More than a billion people lack access to sufficient quantities of clean drinking water, and nearly double that number have no access to even basic sanitation services. An estimated ten thousand people die each day from diseases or the impacts of drinking contaminated water - nearly four million each year (UNESCO, 2009). All of this "hard data" include error bars and imprecisions. If there was ever a place to "lie with statistics," the subject of water is that place. Additionally an even larger gap separates awareness of water problems and acceptable solutions (Varady et al., 2008). And while we may never agree on all the details, it is clear that adopting water goals and targets through an enforceable convention or treaty would send a clear message that policymakers should focus on this impending threat with more precision and clarity (Varady et al., 2009).

Language and understanding, whether about subjective concepts or objective data, evolve together. The analysis of Hoekstra and Chapagain (2008) of published volumes on global water problems illustrates the process. For example, they state that early works used 'global'...to mean 'widespread.' What has changed over the years is recognition that "water problems are often caused by mechanisms that can be understood only at a level far beyond that of the river basin...and closely linked to the structure of the global economy." They argue that water itself has become a globalized resource requiring new terminology, and new mechanisms for interaction and policy making. And who would argue with the history of water quality standards; as we learn more about toxins, our understanding of their impacts also becomes more precise.

Debate surrounding this theme may eventually lead to one or more international water agreements and perhaps legally enforceable goals such as those relating to quality standards, the provision of water by water-rich countries (both real and virtual) with water-poor countries on a concessionary basis or even as part of their official development assistance (ODA) efforts, among many other possibilities. One option that has been informally discussed is that lending institutions could require that certain quality and quantity standards be met as part of any loan agreement. But it is clear that there are no easy solutions to this complex issue (Note 3).

\section{A Brief Overview of the Global Water Debate}

Tracing the history of water governance is a complicated, even daunting, exercise in part because of the many government agencies, academic institutions and non-governmental groups that address the various issues related to water use and management at local, regional and global scales. A simple web search for 'water history' yields in excess of 25 million references while 'water governance' produces in excess of 16 million references. Since the early 1970s, there have been thousands of meetings to address the management and use of water with varying degrees of success. What is clear is that the two Millennium Development goals (MDGs) relating to water and sanitation will not be met by 2015 as originally proposed nor by the extended date of 2025 now being informally discussed (Note 4). It seems that no matter how much is invested in the sector, population growth, increasing 
capital investment costs and the millions of people displaced due to conflicts and natural disasters will continue to keep established targets out of our collective reach.

The 1972 Stockholm Conference on Environment and Development, one of the earliest international meetings to structure debate on water, had a very broad, even idealistic agenda that focused world attention on the problems of environmental quality and the inequities and often short-sightedness of the development process. As a result of the Stockholm Declaration on the Human Environment, the United Nations Environment Programme (UNEP) was established and freshwater was considered part of its portfolio. However, the very broad mandate for this new organization developed by the Member States meant that UNEP in its more than 40-year history has had only a marginal impact on the global freshwater agenda and ensuing policy. Budget and staff limitations never kept pace with the scale of the problem.

The availability and quality of freshwater as discernable intergovernmental issues can be traced to the Mar del Plata Conference in 1977 and its plan of action which sought both to avert future water crises and to provide a framework that looked toward tangible outputs at national, regional and international levels. This was also the first time that water was discussed as a human right (Hiwasaki, 2012). Some regional bodies, such as the Organization of American States (OAS) and the Asian Development Bank (ADB), used the action plan to focus its technical assistance work on what today would be called "integrated water resource management (IWRM)." Generally, however, most governments did not fully grasp the importance of water as a driver of development and investment until some years later.

The UN declared 1981-1990 as the first International Drinking Water and Sanitation Decade, a step that led to several regional conferences including: the 1990 Global Consultation on Safe Water and Sanitation for the 1990's in New Delhi, and the 1992 International Conference on Water and the Environment (ICWE) held in Dublin, Ireland. The latter gathering provided the issue of water a much more visible profile as a crosscutting and integrating theme for economic development. More than 100 countries and 80 NGOs participated in the conference and the Dublin Principles still serve as the baseline against which progress in the international water agenda is measured. Summarizing, these principles are that: (i) fresh water is a finite and vulnerable resource, essential to sustain life and development; (ii) water development and management should be based on a participatory approach, involving users, planners and policy-makers at all levels; (iii) women play a central part in the provision, management and safeguarding of water; and (iv) water has an economic value in all its competing uses and should be recognized as an economic good. For many, this outcome represented a tangible step forward in our collective understanding.

The Earth Summit held in Rio de Janeiro in mid-1992 focused the attention of world leaders on the integrated nature of environment and development. While water was not the focus of that meeting, the context of sustainable development and the integrated nature of the world we live in was now firmly in place. Shortly after Rio, the UN Commission on Sustainable Development (CSD) was created to continually evaluate progress made on the many mandates of the Earth Summit's Agenda 21. Both CSD-12 in 2004 and CSD-13 in 2005 placed water and sanitation as principle points on their agenda and CSD-16 in 2008 included drought and desertification among the points to be looked into.

In 1995 and 1996, four UN meetings (water and poverty/social development, water and gender, water and the special needs of urban areas, and water and food production) brought water to the attention of the scientific community as well as to a burgeoning environmental NGO movement (Note 5).

The pace and focus of 'water meetings' increased with the formation of the World Water Council in 1996 and the First World Water Forum in Morocco (1997) (Note 6) which underscored the importance of the Dublin Principles within the policy context outlined in Rio. And, as noted above, the UN Millennium Summit (September, 2000) resulted in the MDGs. The following year, the International Conference on Freshwater (Bonn, Germany) sought specific commitments from UN Member States towards meeting the MDGs. A Second World Water Forum held in The Hague in 2000 included the suggestion that an international agreement or convention might be needed to address the ever more complex water related issues important for management of the world's 261 transboundary river basins (Wolf, 1999).

The Millennium Summit held in New York in 2000 developed the Millennium Development Goals (MDGs) and the Targets related to water and sanitation. Declarations and ministerial statements emanating from the World Summit on Sustainable Development in 2002 (Rio+10) held in South Africa noted the importance for the world community to address water issues in a more formal manner, including investments, if the millennium development goals are to be met. Many other meetings, such as the annual Stockholm Water Week, regional meetings of the Inter-American Water Resources Network (IWRN), establishment of UN Water, and the water 
committees of the Asia-Pacific Economic Cooperation Forum (APEC), the African Ministers' Council on Water (AMCOW) and the regional development banks gave increasing urgency to the needs of the water sector as critical to world peace and progress (Note 7). Finally, the 2005-2015 Decade for Action: Water for life set a timetable for achieving the MDGs.

After all this debate and the increase in awareness surrounding what can only be described as a growing freshwater crises, the next logical step might be for the international community to consider some sort of an international accord. But to date that has not materialized.

\section{An Architecture of Global Water Governance}

Global governance, despite agreed upon instruments, often fails because and the institutions required to interpret, administer and enforce the instruments of governance are often weak, with little or no power over sovereign governments. Without a strong architecture agreements may languish and action plans fail to meet the goal that were so carefully outlined. Despite an agreed upon text, an organizational home, and a well-funded, viable and qualified secretariat, things go awry because of the so-called "wicked problems;" reaching agreement on the most basic of issues is fraught with pitfalls that can appear at any stage in the process (Note 8), fomented by cultural differences, historic land use patterns, economic tensions, social and educational levels, among many other factors.

Major questions emerge as a result of these difficulties: How should the world community work within this complexity of response regarding a perceived need for a water agreement? What would a global water agreement look like? Who would administer and enforce it? Would a WTO-like mechanism for enforcing water quality or quantity standards? Many stakeholders argue for a formal treaty or convention while others worry about its enforceability. Which is correct? Some feel that water is a national issue, and that transboundary agreements should be made without the interference of non-parties; and others argue that water-rich countries have an obligation to water- poor countries and that these can only be addressed through an international accord of some type. Such questions are difficult but their answers may reside in a concept that guides recent and current meetings that many of the previous meetings did not have: acknowledgment that water is a human right.

\section{Water Conflict and Water as a Human Right}

Without question conflicts over water are as old as humanity itself. Gleick and Heberger (2014) document more than 265 such encounters from as early as 3000 B.C.! However Wolf (1998) claims that "a close examination of the case studies cited as historic interstate water conflicts suggest some looseness in classification. "He further notes that "the actual history of armed water conflict is somewhat less dramatic then the "water wars" literature would lead one to believe: a total of seven incidents, in three of which no shots were fired..." (Wolf, 1998). And for the first time Jarvis has undertaken an analysis of water conflict issues in groundwater, a resource that will become increasingly important as surface water sources are depleted or further compromised through pollution and increasing costs of treating it for human consumption. He notes "whereas surface watersheds are static, groundwater boundaries are value-laden and constantly changing during development" (Jarvis, 2014). Regardless of the interpretation of "conflict" or the so-called "water wars", or the complexity of trying to negotiate a solution to water that can't even be seen, the international community should dedicate itself to better defining issues relating to access and use of water; it will benefit all in he short and long-term.

One of the most scholarly works on the access and use of shared resources is that of Ostrom (1990). He defines "common pool resources" (CPRs) as including those sufficiently large as to make it costly to exclude beneficiaries from obtaining the benefits (goods and services) provided by the system. Certainly a shared water resource (surface or ground water) would qualify as a CPR. Wolf (1998) would undoubtedly agree that the investment in finding a solution benefits all involved. Furthermore, once cooperative water regimes are established through treaty, they turn out to be impressively resilient over time, even between otherwise hostile riparians, and even as conflict is waged over other issues. These patterns suggest that the more valuable lesson of international water is as a resource whose characteristics tend to induce cooperation, and incite violence only in the exception (Wolf, 1998). So, let's assume then that water ever the level of investment - time and financial underpinning, political capital, finding a solution is a desirable outcome.

Water has long been considered a strategic resource for both sustainable development and security. However in 2002, safe and secure drinking water was declared a basic human right through acceptance of General Comment No. 15 of the UN Committee on Economic, Cultural and Social Rights; putting the need for an international agreement in a totally new and very bright light. This statement also encouraged the 145 signatories to the International Covenant on Economic, Cultural and Social Rights to treat access to water as a basic human right and not merely an economic commodity. Article I.1 states: "The human right to water is indispensable for leading a life in human dignity. It is a prerequisite for the realization of other human rights". Comment No. 15 also defined 
the right to water as the right of everyone to "sufficient, safe, acceptable and physically accessible and affordable water for personal and domestic uses" (UNCESCR, 2002) (Note 9). In the following year, the UN Security Council noted that water had taken on such importance in the debate relating to international economic development and stability that it is "paramount to global stability and prosperity" (UNGA, 2003). On 28 July 2010, through Resolution 64/292, the United Nations General Assembly explicitly recognized the human right to water and sanitation and acknowledged that clean drinking water and sanitation are essential to the realization of all human rights. The Resolution calls upon States and international organizations to "provide financial resources, help capacity-building and technology transfer to help countries, in particular developing countries, to provide safe, clean, accessible and affordable drinking water and sanitation for all" (UNGA, 2010).

Other meetings showing interest in the subject closely followed the agendas and outcomes of UN meetings. The Earth Dialogues organized by Green Cross International in Lyon, France in 2002 and consultations during a series of gatherings including the 2002 World Summit on Sustainable Development (WSSD), the 2003 World Water Forum in Japan, and other meetings, resulted in an unpublished 'non-paper' entitled 'Fundamental Principles for a Framework Convention on the Right to Water' (Green Cross International, 2005). Supporting text for the agreement reads in part:

The right to water is essential for securing social justice, dignity, equity and peace, and its implementation would guarantee sufficient, acceptable and non-discriminatory access to water for all, while fostering a sense of responsibility on the part of users... Considering that water is required for a variety of uses and fulfills multiple functions for human being, water ecosystems and development, this initiative - in conjunction with all other actions in favor of the fundamental right to access to water and sanitation for all - reaffirms that the recognition and implementation of this right:

- are indispensable to the realization of other rights: the right to life, the right to dignity, the right to health, the right to food, the right to peace, the right to a safe environment, and right to development;

- are essential from the standpoint of sustainable development;

- would reinforce the participation and collaboration of all parties: taken as an economic cultural and social right, the right to water is a source of synergy among all development actors (Green Cross International, 2005).

In part as a response to this undercurrent of support from many sectors of the global community, the South African Supreme Court ordered the City of Johannesburg to provide a minimum of 6000 liters of water each month to each household. Above this amount rates paid for water are "adjusted according to the use of water and the user's socio-economic status. Prices rise as more water is withdrawn, with especially steep tariffs applied to luxury water use, large landowners and industry" (Haffajee, 1999). In the ruling, the presiding Judge noted that "Water is life, sanitation is dignity - this case is about the fundamental right to have access to sufficient water and the right to human dignity" (Green Cross International, 2005). Thus, the theme of WWF2 (The Hague), "From Vision to Action," sought to move from theory toward action and the Ministerial Declaration was replete with 'action' language and commitments from governments. Unfortunately, rather than catalyze actions and further pro-active discussions among governments and donors, subsequent WWF gatherings saw the idea of an action agenda nearly die. Ministerial Declarations from both Kyoto and Mexico saw few 'will' statements mustering only that they 'should,' or that they 'reaffirm' or 'consider' actions to be taken. Evidently, the relatively low level of government representatives at the preparatory meetings, and control exerted by the Ministries of Foreign Affairs rather than by technical specialists over the agenda exacerbated by unclear and overlapping objectives and few commitments from the development banks led to this disappointing outcome.

The Pontifical Council for Justice and Peace clarified its stance in a very strong statement that "as a gift from God, water is a vital element essential to survival, thus everyone has a right to it" (Pontifical Council for Justice and Peace, 2006). And the World Council of Churches has issued many similar statements and noting that without access to clean water in sufficient quantities all other human rights are threatened (World Council of Churches, 2011).

Still, water as a human right is a strong enough pull that efforts continue to support the establishment of a viable action agenda. This call for change can be seen through the objectives and the increasingly important role being played by technical water specialists from the host government and the World Water Council (WWC) in the planning process for its 2015 Forum in Korea.

Three overarching concepts that reflect changes in both process and anticipated outcomes for the WWF7 include: (i) increasing the quality of the Forum (as measured by an action agenda), (ii) bridging divides for water among all actors and all interests and (iii) enhancing global visibility of forum outputs. This sets a high bar for the Forum's expected outcomes: a 'Plan of Action,' a 'Global Water Compact' (Note 10), and a possible 'Global Water 
Convention.' All of this is ambitious to be sure but it is necessary in order to reach a water agreement that is both efficient and effective. In addition, the processes leading up to the meeting will help focus world attention on the work ahead and draw opinions from a wide swath of government and civil society. Once a public commitment is made, other groups (academia, municipalities, NGOs, research institution, and the private sector) come forward to enrich the debate and help to create a critical mass of support.

\section{Is a Global Water Regime Needed?}

Obviously, given the trends that opened this discussion, previous efforts to build, finance, and enforce actions regarding the place of water in the life quality of the world's populations have been insufficient. There have been few meaningful commitments or coordinated actions at the global level by governments. This, despite calls for action to relevant United Nations bodies, specialized agencies, regional commissions and other organizations of the United Nations system to "deliver a coordinated response, utilizing existing resources and voluntary funds, during the decade 2005-2015" (UNGA, 2003), and hundreds of "water agreement signed in the last 50 years (Wolf, 1998).

This call from the UN General Assembly paves the way for nations to act with regard to water resources and services and help governments and banks to agree on actions for water under a global accord. It also provides a convenient way to initiate formal talks about a Convention or Compact. However, perhaps the strongest argument for a global instrument is that if serious action is not taken on the crosscutting issue of water, it is very likely that the world will fail in meeting the MDGs. For better or worse, the MDGs have clearly dominated the international development agenda and water is principal to its realization.

\section{Implementation - What Would a Global Water Regime Look Like?}

A governance regime, by definition, includes formal and informal institutional arrangements that study, finance, manage and administer a common property resource or issue area. Such agreements would penetrate all levels of government and, for water, could include the following:

- CONVENTION. A global water convention would be a text negotiated by national governments to include global principles related to water resources and services and, when ratified, would bind its signatories to a given set of goals and responsibilities. Such a text would be negotiated through the United Nations within the framework of a full-fledged intergovernmental process and eventually find its way into the priorities of development banks and official development assistance (ODA) objectives. Before entering into force, it must also be ratified by the requisite number of Member States.

- COMPACT. A global water compact would be a set of voluntary actions and principles negotiated by a select group of national governments and civil society participants (sub-national governments) (Note 11).

- PLAN OF ACTION. A plan of action would be an extended list of actions and responsibilities negotiated by national governments through an intergovernmental process finalized at the ministerial level of an international meeting.

Convention. The process of negotiating a water convention could begin on two levels: in the UN and in the WWC and would require an effort to organize a special session of the UN General Assembly fed by the preparatory process of a World Water Forum. This is a time consuming effort requiring a government or group of governments to propose a special session of the U.N. General Assembly to pass a resolution creating a secretariat that would organize the negotiation process among the Member States (Note 12). As two-thirds of the Member States must agree, a strong diplomatic champion is vital before any real process can be charted. A part of the resolution would designate a lead agency to eventually house the convention secretariat. This institution would require a wide range of political, scientific, and technical expertise. To establish connections between the UN, civil society, professional communities, and the WWF planning process, a technical advisory board (TAB) could be established based on recommendations by the WWC. Organized in this way, the differences between political and technical positions evident in past forums could be successfully bridged.

Work on behalf of World Water Forum can move forward simultaneously with that of the UN. This is important, because if the U.N. General Assembly approves a resolution to establish a secretariat and the negotiating process, the themes that are worked on during forum planning will feed directly into what may eventually become a Global Water Convention.

Water Compact. The process to produce a water compact would start much like that for a global water convention, except that the UN is not required to act as a vehicle of negotiations. Its aim is to include more than national governments. With the successful inclusion of parliamentarians and local authorities in WWF4, the International Scientific Committee decided to maintain this integrating effort for future water forums and to take it a step further 
to include local forms of governance. Creating a global water compact between sub-national governments, and civil society can push the technical agenda forward and enrich the UN debate.

Negotiation of a compact would be very difficult if it were meant to be a binding agreement. The logistics of trying to negotiate a document with potentially tens of thousands of participants would be impossible. The idea is to bring together 100-150 local authorities and a similar-sized group of parliamentarians and other members of civil society to develop a compact of principles and actions that sub-national governments would submit themselves to on a voluntary basis. This would not require the participation of thousands of local authorities but rather a representative group that could craft a common sense document which others could become a part of that pushes elected officials to act.

The benefits of such a Compact are many. Under its auspices sharing of best practices and lessons learned are facilitated. Additionally, by allowing proactive stances on water-related issues, risks can be better managed, awareness can be raised, and solidarity formed. If nations are not willing to sign onto a plan of action or convention, sub-national governments can still do so through the compact (Note 13). A compact can also function by itself, but would be more effective if it were linked with a convention and plan of action. The themes of the compact would be developed in close relation with the planning process for future world water forums.

Plan of Action (PoA). No matter what the outcome of the political process of future WWF meetings, a plan of action is the minimum product that should be agreed on. Ideally, negotiation of a plan of action would also be through the United Nations following a process similar to that used for a global water convention and would also require a resolution in the UNGA. The plan of action would focus on commitments rather than principles and identify multi-national regional actions as opposed to a convention's national level goals.

Global Water Regime. These three alternatives are not mutually exclusive and, most importantly, they will be stronger when enacted together.

Negotiation and implementation of a convention, a compact, and a plan of action together - a global water regime-would include not only the international legal obligations on principles and actions of national governments, but also sub-national governments and regional actions. The themes for each would be very similar, if not identical, in all three documents and linked, just as they are linked through the various levels of government. The principles negotiated for the convention would include the participation of the sub-national governments as well and these same principles can be applied to the compact.

\section{Summary}

Each of the approaches outlined above would be based on the principle that all humans have the right to safe and equitable access to water. National governments would be required to provide water in a safe and equitable manner to all humans regardless of class, race, gender, political affiliation, and religion and will work with both regional and local governments to facilitate the provision of safe water to all. Parliamentarians will eventually be required to work with their governments and local authorities in an efficient and effective manner and be a link between the two levels of government. Overtime national governments would work within a regional or global context to negotiate common goals, targets and an investment and implementation strategy and timetable.

In the end, reaching agreement on a binding international convention or compact is a worthy goal, but one that will require the dedication of many individuals and organizations for an extended period. Still the goal itself is worthy and although a complex process, requiring a fundamental understanding of shared commitments and responsibilities, it has come to dominate the international agenda precisely because there is no alternative.

\section{References}

Gleick, P. H., \& Matthew, H. (2014). Water Conflict: Events, Trends and Analysis. In The World's Water: The Biennial Report on Freshwater Resources (Vol. 8). Pacific Institute.

Green Cross International et al. (2005). Unpublished draft. Fundamental Principles for a Framework Convention on the Right to Water. Geneva.

Haffajee, F. (1999). South Africa: Water for Everyone. UNESCO Courier. February.

Hiwasaki, L. (2012). Water for Life...Water for Whose Life? In B. R. Johnston, L. Hiwasaki, I. J. Klaver, A. Ramos Castillo, \& V. Strong (Eds), Water, Cultural Diversity, and Global Environmental Change: Emerging Trends, Sustainable Futures? Springer 2012.

Hoekstra, A. Y., \& Ashok, K. C. (2008). Globalization of Water. Wiley-Blackwell Publishing, UK. 
Jarvis, W. T. (2014). Contesting Hidden Values: Conflict Resolution for Groundwater and Aquifers. Routledge Publishers.

Ostrom, E. (1990). Governing the Commons: The Evolution of Institutions for Collective Action. Cambridge University Press. http://dx.doi.org/10.1017/CBO9780511807763

Pontifical Council for Justice and Peace. (2006). A Contribution of the Holy See to the Fourth World Water Forum: Water An Essential Element for Life. Mexico City 16-22 March, L'Obssevatore Romano, 19 March 2006, p2.

Saunier, R. E., \& Meganck, R. A. (2009). Dictionary and introduction to global environmental governance (2nd ed.). UK: Earthscan.

UN Water. (2014). A Post-2015 Global Goal for Water: Synthesis of Key Findings and Recommendations from $U N$-Water. Paris.

United Nations Committee on Economic, Social and Cultural Rights. (2002). General Comment No. 15: The Right to Water. New York.

United Nations Education Scientific and Cultural Organization. (2009). UN World Water Development Report, UNESCO, Paris.

United Nations General Assembly. (2003). 58/217. International Decade for Action, Water for Life, 2005-2015. Fifty-Eighth Session of the United Nations General Assembly, Document A/RES/58/217. New York.

United Nations General Assembly. (2010). Water and Human Rights: Resolution A/RES/64/292. New York.

United Nations Wire. (2008). South Africa: court ruling on water sets global precedent. May 8.

Varady, R. G., Meehan, K., \& McGovern, E. (2009). Charting the emergence of 'global water initiatives' in world water governance. Physics and Chemistry of the Earth, Parts A/B/C, 34(3), 150-155. http://dx.doi.org/10.1 016/j.pce.2008.06.004

Varady, R. G., Meehan, K., Rodda, J., McGovern, E., \& Iles-Shih, M. (2008). Strengthening global water initiatives. Environment: Science and Policy for Sustainable Development, 50(2), 18-31. http://dx.doi.org/10.3200/ENVT.50.2.18-31

Wolf, A. T. (1998). Conflict and cooperation along international waterways. water policy, 1(2), 251-265. http://dx.doi.org/10.1016/S1366-7017(98)00019-1

Wolf, A. T. (1999). The transboundary freshwater dispute database project. Water International, 24(2), 160-163. http://dx.doi.org/10.1080/02508069908692153

Anonymous. (2011). World Council of Churches - Ecumenical Water Network. Retrieved from www.oikoumene.org

\section{Notes}

Note 1. Postmedia News. 2014. Interview with Canadian Ambassador to the U.S. conducted by William Marsden. February 24, < o.canada.com>.

Note 2. U.S. President Barack Obama's speech on foreign policy to the 2014 West Point Military Academy graduating class, 28 May 2014.

Note 3. Some examples of agreements where objective standards or targets are defined include: the UN Framework Convention on Climate Change, the Kyoto Protocol, the Vienna Convention for the Protection of the Ozone Layer, the Law of the Sea Convention, the Convention on Biological Diversity, the RAMSAR Convention on Wetlands of International Importance. The Millennium Development Goals (MDGs) identify specific targets but as they have not been ratified as part of a convention, they are not binding and therefore not enforceable.

Note 4. The Millennium Development Goals (MDGs) comprise eight international development goals that were established following the UN Millennium Summit in 2000. Goal seven "ensuring environmental sustainability" includes two targets aimed at reducing the number of people without accesses to clean drinking water and basic sanitation services by $50 \%$ by the year 2015 .

Note 5. World Summit for Social Development, Copenhagen, Denmark 1995 (water, poverty and social development); UN Fourth World Conference on Women, Beijing, China 1995 (gender, water supply and 
sanitation); UN Conference on Human Settlement - Habitat II, Istanbul, Turkey 1996 (urban water); the UN World Food Summit, Rome, Italy 1996 (water and food production/security).

Note 6. World Water Fora: 1997 Morocco, 2000 the Netherlands, 2003 Japan, 2006 Mexico, 2009 Turkey, 2012 France, 2015 Korea, 2018 Brazil.

Note 7. This section of the paper benefited enormously from an unpublished proposal submitted to the WWC and the Turkish Government for review and comment at the 29th BoG meeting of the WWC held in Marseille, France in June, 2007: Priscoli, Jerry Delli, Margaret Pageler, Andras Szöllösi-Nagy, Pierre Victoria and Daniel Zimmer (2007) 'Draft (unpublished) position paper by the WWC Members of the 5th World Water Forum Political Process Committee.' WWC Ref:BoG29.13iii, June, Marseille, France.

Note 8. Two of the earliest examples are those of Favar, Taqhi and John Milton (1972) The Careless Technology: Ecology and International Development. Doubleday Publishers, and Sjostedt, G. (1993) International Environmental Negotiation, London, Sage Publications.

Note 9. United Nations Committee on Economic, Social and Cultural Rights (2002) 'Substantive Issues Arising in the Implementation of the International Covenant on Economic, Social and Cultural Rights.' Twenty-ninth session, Geneva, Agenda Item 3, November. Environmental News Service (2002) Environmental News Service (2002) Water and health declared a human right. $<$ http://ens-news.com/ens/dec2002/2002-12-04-01.asp > Geneva, 5 December Environmental News Service (2003) Environment and human rights linked before UN commission. $<$ http://ens-news.com/ens/apr2003/2003-04-11-01.asp> 15 April.

Note 10. Within the United States, compacts are treaties between U.S. States, which do not fall under the governance of the national government, but which are binding under U.S. law. Internationally, most examples of compacts that could be found (UN Global Compact, the International Compacts for Iraq and Afghanistan, etc.) are not binding under international law, so this allows actors that are not national governments to sign on to them. This is the idea of the "Global Water Compact" - to create a non-binding, negotiated agreement that sub-national actors can consent to it voluntarily.

Note 11. Sub-national governments, in this text, refers to all members of civil society who are not part of the national government - authorities from municipalities, provinces, states, departments, NGOs, private firms, parliamentarians and academics.

Note 12. The same approach was followed in launching the current U.N. International Decade on Water for Life and in starting the debate on the Convention on Biological Diversity.

Note 13. Much like how there are over 400 cities in the United States that have voluntarily agreed to abide by the Kyoto Protocol even though the national government has not done so.

\section{Copyrights}

Copyright for this article is retained by the author(s), with first publication rights granted to the journal.

This is an open-access article distributed under the terms and conditions of the Creative Commons Attribution license (http://creativecommons.org/licenses/by/3.0/). 